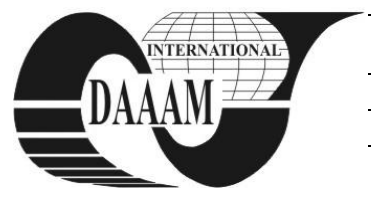

\title{
REVIEW OF FUTURE CHANGES AND CHALLENGES OF PRODUCTION COMPANIES
}

\author{
PALCIC, I[ztok]; BUCHMEISTER, B[orut]; PAVLINJEK, J[oze] \& VEDENIK, G[regor]
}

\begin{abstract}
In the paper a resource-oriented perception and findings of sustainable management is presented. Our times are characterized by the growing complexity of the systems and their dynamic interactions. Firms that decide to act more sustainable have to bear in mind that they do not only need resources for economic activities today, but that they will need these tomorrow as well. This leads to contradictory management rationalities firms must deal with. The authors present a holistic view of the development, with changes and new directions in different production relating areas (materials and technology trends, energy trends, ecology and environment, organization, customers, products).
\end{abstract}

Key words: trends, development, technology, business process, sustainability

\section{INTRODUCTION}

Climate change and finite resources are beginning to affect every organisation - big or small, public, private or non-profit and irrespective of its geographic location or type of business. In a fast changing global scenario all economies are being reshaped, businesses are being repositioned, green investments are growing and consumers are calling for cleaner world economy. So, this is a very interesting topic for investigation.

Transition from high to low carbon and more sustainable economies has begun. It is therefore no longer a matter of choice for organizations to go green or continue doing business as usual. It is - in fact - a business imperative to incorporate environmental sustainability in all their operations. The regulatory requirements for protecting the environment are becoming ever more stringent and the consumer demands for eco-friendly products and services are at all time high.

Development trends affecting economics, the environment, technology, customers and competitors are listed in Table 1.

\section{CHANGES IN OBSERVED FIELDS}

\subsection{Materials}

Materials have shaped the history. New material technology paves the way for progress in other technological areas. New materials offer a high potential for sustainable development, such as the use of renewable resources and replacement of environmentally harmful substances (Müller \& Glutsch, 2007).

\subsection{Technology}

Technology has been one of the main engines of economic development since the industrial revolution (Zeleny, 2009). Globalization, growing demand for services, new organizational models - the working world in industry is rapidly changing (Kehris, 2009). Researchers investigated the impact of three highly differentiated technologies on industrial work of the future: Biotechnology, Nanotechnology and Ambient Intelligence.

In the departments for product and process development and innovation management are the higher opportunities to reduce costs, eliminate waste and improve quality than in production (Kosturiak, 2009; Kremljak et al., 2005).

\subsection{Energy}

The EU wants to obtain one fifth of its energy from renewable sources by 2020 . This 20 percent target is realistic for the final energy generation of electricity, heat and bio fuel.

The direct and later the indirect co-firing of biomass in fossil-fuelled power stations will become more relevant. Of the other renewable energies, wind and photovoltaic may continue to be growth markets. But commercial-scale solar thermal power also has good market prospects.

\subsection{Ecology}

Ecology is good business! The processes of recycling, resource recovery, material reduction, product reuse, remanufacture and systems redeployment lead to innovation and the reinstatement of the business life-cycle (Zeleny, 2009).

\begin{tabular}{|c|c|}
\hline \multirow{8}{*}{ 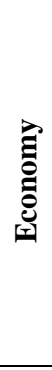 } & Increasing productivity, increasing automation \\
\hline & Growth in service industries \\
\hline & Increasing globalization, greater capital mobility \\
\hline & $\begin{array}{l}\text { More frequent relocation of businesses, depending on } \\
\text { conditions for business }\end{array}$ \\
\hline & Virtualization of companies \\
\hline & Knowledge as the most important resource \\
\hline & $\begin{array}{l}\text { New business models through electronic and mobile } \\
\text { business }\end{array}$ \\
\hline & Continued reduction in the length of product life cycles \\
\hline \multirow{6}{*}{ 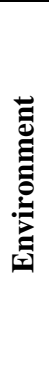 } & Increasing environmental awareness \\
\hline & $\begin{array}{l}\text { Sustainability/regulation of all intermediate and end } \\
\text { products }\end{array}$ \\
\hline & $\begin{array}{l}\text { Increasing importance of recycling - new laws and } \\
\text { regulations }\end{array}$ \\
\hline & Sparing use of resources \\
\hline & $\begin{array}{l}\text { Alternative raw materials and energies, renewable } \\
\text { energies }\end{array}$ \\
\hline & $\begin{array}{l}\text { Environmental disasters and new illnesses with } \\
\text { widespread effects }\end{array}$ \\
\hline \multirow{7}{*}{ 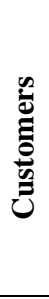 } & Individualization of lifestyles \\
\hline & Increased expectations as regards quality and service \\
\hline & Standardized, process-based buyer-vendor relationships \\
\hline & Increased efficiency as a result of intelligent solutions \\
\hline & Well-informed customers \\
\hline & Outsourcing / partnering \\
\hline & $\begin{array}{l}\text { Rapidly growing importance of electronic, mobile and } \\
\text { real-time business }\end{array}$ \\
\hline \multirow{6}{*}{ 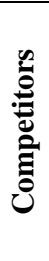 } & Reduced costs / increased productivity \\
\hline & $\begin{array}{l}\text { Lower barriers to entry in new fields of business as a } \\
\text { result of electronic media }\end{array}$ \\
\hline & New competitors from other industries \\
\hline & Shorter life cycles of products and services \\
\hline & Intensive price wars for market share \\
\hline & Growing importance of brand and image \\
\hline
\end{tabular}

Tab. 1. Observed trends of future development 


\subsection{Environment}

It is evident for the people that the higher their standard of living, the more critical the situation becomes for the environment. We have to do everything within our power to protect the environment and conserve resources. This includes examining every stage of a product's life cycle with a view to conserving resources and promoting sustainability and then adapting it (Berner, 2004)

\subsection{Organization of business processes}

Productivity, flexibility and quality are essential competitive factors, closely related to the way business processes are organized within the company. Innovation must generate something new for the customer life - simplification, risk elimination, convenience, better price, fun, image and emotions, style or environmental friendliness (Kosturiak, 2009; Lestan et al., 2009).

Companies have responsibility for the general well-being of society beyond short-term economic self-interest. At the level of the individual, this means devising jobs and work patterns which allow individuals to contribute their talents without undue stress. At a group level, it means recognizing and dealing honestly with employee representatives. This principle also extends beyond the boundaries of the organization (Slack et al., 2010).

In the future a lot of new ways of doing business will appear. Development from e-business to e-value-chains, ecompanies, e-markets and finally e-world is expected.

The market's needs and expectations of performance objectives will vary. The extent to which an operation meets market requirements will also vary. In addition, market requirements and the operation's performance could change over time (Fig. 1). The role of the manufacturer over the entire product life cycle is changing, and manufacturers' overall responsibilities for their products are increasing significantly.

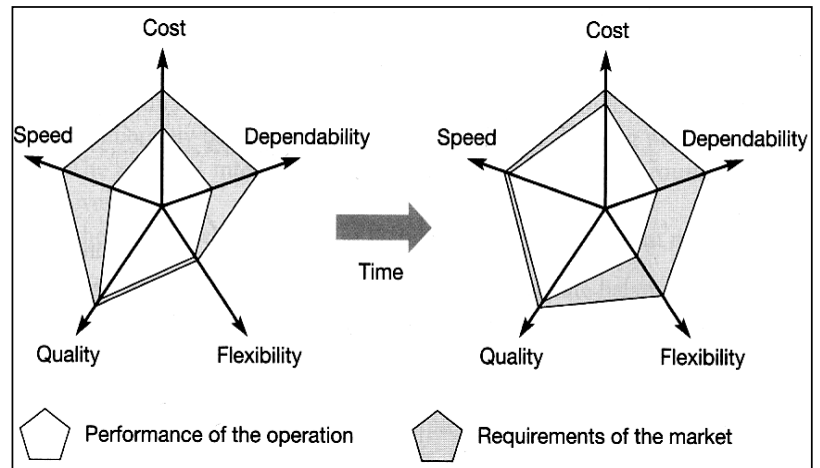

Fig. 1. Customers' needs and operation's performance changes (Slack et al., 2010)

\section{CONCLUSION}

Our planet's survival requires us to consider sustainability in our decisions. The authors contribute with the review and forecasts for future changes towards sustainable businesses. Time and knowledge are becoming decisive factors.

The great challenge facing us today and in the future is best described as continuous renewal. This is an imperative that applies not only to business but also to science, government and society as a whole. Reducing the dependency of our society on raw materials and energy consumption through increased material efficiency and innovative, resource-efficient product ideas are promising concepts. The key areas of technology that will have most influence on developments in the $21^{\text {st }}$ century are shown in Fig. 2.

Being sustainable means combining a holistic approach with sustainability. It means shaping the present in the knowledge of traditions, with courage for new ideas and responsibility for the future, where we will be faced with changes and challenges in all the different spheres of our lives.

As a result of the explosive growth in the networking of both people and machines, the speed of progress will increase further. Companies must invest in process evolution, productivity or paradigm-free innovations to be among the winners in the future, creating new value, new jobs, and new prosperity for the mankind (Berner, 2004).

Current and emerging research in this area includes:

- Eco-efficiency: Using operations management tools to reduce environmental impact;

- Product stewardship: Analysis of closed-loop supply chains, eco-labelling, green sourcing, carbon foot-printing, design for the environment;

- Sustainable technology: Analysis of novel operational problems faced by organizations that develop or adopt new products or services;

- Sustainable development: Application and adaptation of operations management concepts and tools.

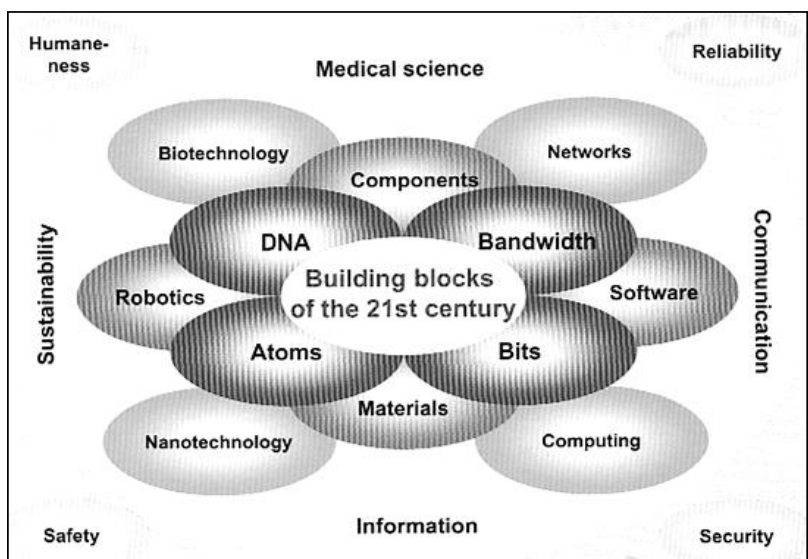

Fig. 2. Building blocks of the $21^{\text {st }}$ century (Berner, 2004)

\section{ACKNOWLEDGEMENT}

The research was partly realized within the activities of the CEEPUS II Project (CII-RS-0065-04-0910). The authors would like to thank the network coordinator for his valuable support.

\section{REFERENCES}

Berner, G. (2004). Management in 20XX, Publicis Corporate Publishing, Erlangen

Kehris, E. (2009). Web-based simulation of manufacturing systems. Int. Journal of Simulation Modelling, Vol. 8, No. 2, pp. 102-113

Kosturiak, J. (2009). The new role of industrial engineering in a flat world. Acta Mechanica Slovaca, Vol. 13, No. 1, pp. 8892

Kremljak, Z.; Polajnar, A. \& Buchmeister, B. (2005). A heuristic model for the development of production capabilities. Journal of Mechanical Engineering, Vol. 51, No. 11 , pp. 674-691

Lestan, Z.; Brezocnik, M.; Buchmeister, B.; Brezovnik, S. \& Balic, J. (2009). Solving the job-shop scheduling problem with a simple genetic algorithm. Int. Journal of Simulation Modelling, Vol. 8, No. 4, pp. 197-205

Müller, B. \& Glutsch, U. (2007). Annual Report 2007, Fraunhofer Institute for Systems and Innovation Research ISI, Karlsruhe

Slack, N.; Chambers, S. \& Johnston, R. (2010). Operations management, FT Prentice Hall - Pearson, Harlow.

Zeleny, M. (2009). Technology and high technology - Support net and barriers to innovation. Acta Mechanica Slovaca, Vol. 13, No. 1, pp. 6-19 